\title{
Perbandingan kadar magnesium serum setelah terapi magnesium sulfat rute berbeda pada preeklampsia
}

\author{
Lily Marliany Surjadi ${ }^{1}$, Djaswadi Dasuki ${ }^{2}$, Mustofa ${ }^{3}$
}

\begin{abstract}
ABSTRAK
\section{LATAR BELAKANG}

Preeklampsia merupakan penyakit hipertensi dalam kehamilan yang menjadi masalah terburuk dalam bidang obstetrik. Sepuluh persen dari seluruh kehamilan mengalami preeklampsia, dan menjadi salah satu penyebab utama kesakitan/kematian. Diperkirakan setiap tahun terjadi 5060 ribu kematian akibat preeklampsia di seluruh dunia. Magnesium sulfat dipakai sebagai obat terpilih untuk preeklampsia, dan diberikan dengan mengikuti protokol Pritchard atau Zuspan. Efek magnesium berguna dalam mencegah komplikasi lebih lanjut dari preeklampsia, namun intoksikasi magnesium dapat menyebabkan depresi pernafasan sampai kematian. Penelitian dilakukan untuk membandingkan kadar magnesium serum pada rute pemberian yang berbeda dan membandingkannya dengan kadar terapeutiknya.
\end{abstract}

\section{METODE}

Penelitian ini merupakan uji klinik secara acak pada 70 penderita preeklampsia yang dibagi menjadi 2 kelompok. Kelompok pertama mendapat protokol Zuspan (intra vena $=$ IV) dan kelompok kedua dengan protokol Pritchard (intra muskuler=IM). Kriteria inklusinya adalah semua penderita dengan preeklampsia/eklampsia, semua usia dan paritas, kehamilan tunggal dan hidup, bersedia mengikuti penelitian. Kriteria eksklusinya adalah komplikasi perdarahan antepartum atau penyakit kronis, misalnya diabetes mellitus (DM) dan atau gangguan fungsi ginjal, dan memiliki kontraindikasi untuk terapi magnesium. Uji independent sample $\mathrm{t}$ test digunakan untuk analisis data dengan tingkat kemaknaan $\mathrm{p}<0.05$.

\section{HASIL}

Rerata kadar magnesium kedua kelompok tidak menunjukkan perbedaan $(\mathrm{p}>0.05)$ kecuali pada menit ke $10(\mathrm{p}=0.005)$. Kelompok IM menunjukkam rerata lebih tinggi daripada kelompok IV, tetapi masih berada dalam kadar terapeutik.

\section{KESIMPULAN}

Dosis magnesium yang lebih tinggi pada protokol Pritchard (IM) menyebabkan kadar dalam serum yang lebih tinggi dibanding kelompok IV, namun aman karena masih berada dalam kadar terapeutik.

Kata kunci : preeklampsia, terapi magnesium, kadar magnesium serum
${ }^{1}$ Departemen Obstetri dan

Ginekologi, Fakultas Kedokteran

Universitas Trisakti, Indonesia

${ }^{2}$ Departemen Obstetri dan

Ginekologi, Fakultas Kedokteran,

Kesehatan Masyarakat dan

Keperawatan UGM, Indonesia

${ }^{3}$ Departemen Farmakologi dan

Terapi, Fakultas Kedokteran,

Kesehatan Masyarakat dan

Keperawatan UGM, Indonesia

\section{Korespondensi:}

Lily Marliany Surjadi

Departemen Obstetri dan

Ginekologi, Fakultas Kedokteran

Universitas Trisakti, Indonesia,

Jalan Kyai Tapa No. 260, Grogol,

Jakarta Barat

Email: lily0712@trisakti.ac.id

J Biomedika Kesehat 2019;2(3):92-98

DOI: 10.18051/JBiomedKes.2019.

v2.92-98

pISSN: 2621-539X / eISSN: 2621-5470

Artikel akses terbuka (open access) ini didistribusikan di bawah lisensi Creative Commons Attribution 4.0 International (CC-BY 4.0) 


\section{ABSTRACT}

\section{Comparison of serum magnesium level of different route in magnesium sulfate therapy in preeclampsia}

\section{BACKGROUND}

Preeclampsia is a hypertensive disease in pregnancy which is the worst problem in the obstetric field. Ten percent of all pregnancies experience preeclampsia and are one of the leading causes of morbidity/death. Base on estimated that every year 50-60 thousand deaths occur due to preeclampsia throughout the world. Magnesium sulfate is used as the drug of choice for preeclampsia, and is administered following the Pritchard or Zuspan protocol. The effect of magnesium is useful in preventing further complications of preeclampsia, but magnesium intoxication can cause respiratory depression to death. The study was conducted to compare serum magnesium levels in different administration routes and compare them with therapeutic levels.

\section{METHODS}

This study was a randomized clinical trial of 70 patients with preeclampsia who were divided into 2 groups. The first group got the Zuspan (intra venous=IV) protocol and the second group with the Pritchard (intra muscular=IM) protocol. The inclusion criteria were all patients with preeclampsia / eclampsia, all ages and parity, single and living pregnancies, willing to participate in the study. Exclusion criteria are complications of antepartum bleeding or chronic diseases, such as diabetes mellitus (DM) and/or impaired kidney function, and are contraindicated for magnesium therapy. Independet sample t test was used to analysis data with $\mathrm{p}<0.005$.

\section{RESULT}

The mean of magnesium levels between two groups showed no difference ( $p>0.05)$ except at the 10th minute $(p=0.005)$. The IM group showed a higher rate than group IV, but it was still in therapeutic levels.

\section{CONCLUSION}

Higher magnesium doses in the Pritchard (IM) protocol cause higher serum levels compare to IV group, but are safe because they are still in therapeutic levels.

Keywords : preeclampsia, magnesium therapy, serum magnesium levels

\section{PENDAHULUAN}

Preeklampsia merupakan salah satu bentuk penyakit hipertensi dalam kehamilan yang menjangkiti sekitar $10 \%$ kehamilan. Penyakit ini tetap merupakan masalah obstetrik yang belum terpecahkan dan menjadi salah satu dari 3 penyebab utama kematian maternal (bersama dengan perdarahan dan infeksi), dan terjadi sekitar 50-60 ribu kematian yang berhubungan dengan kejadian preeklampsia per tahun di seluruh dunia. (1) Preeklampsia merupakan kelainan yang unik, yang disebabkan karena adanya plasenta dengan patogenesis yang sampai saat ini belum dimengerti seluruhnya. $^{(2)}$ Kelainan ini memiliki spektrum klinis yang sangat bervariasi, bisa dalam bentuk hipertensi disertai proteinuria yang asimptomatik saja, sampai kondisi yang terburuk dengan kegagalan organ multipel. ${ }^{(3)}$

Sampai saat ini, patofisiologi preeklampsia masih belum dapat dijelaskan dengan lengkap. (2-5) Saat ini, patogenesis yang paling penting adalah adaya plasentasi yang tidak sempurna, predisposisi genetik, maladaptasi sistem imun, toleransi yang buruk terhadap perubahan inflamasi menyeluruh, faktor angiogenik - antiangiogenik yang tidak seimbang dan nutrisi yang buruk. ${ }^{(2,6)}$
Disfungsi endotel diketahui memiliki peran sentral dalam kejadian preeklampsia, ${ }^{(7)}$ menyebabkan munculnya respons inflamasi sistemik yang pada akhirnya tampak sebagai gejala preeklampsia. Banyak senyawa kimia termasuk oksida nitrat (nitric oxyde $=N O$ ) yang diproduksi oleh sel endotel, berfingsi untuk mengatur tonus vasomotor. Sel endotel juga mempunyai peranan dalam proses koagulasi, agregasi trombosit dan adhesi sel-sel inflamasi. ${ }^{(8,9)}$

Spasme vaskuler adalah kondisi yang sering dijumpai pada penderita preeklampsia, disebabkan karena gangguan invasi sel trofoblas ke dalam arteri spiralis selama plasentasi. Kondisi ini akan berakhir dengan terjadinya iskemia plasenta, yang berpengaruh pada aktivasi/ disfungsi sel endotel, yang selanjutnya akan melepaskan oksigen radikal dan lipid peroksidase. (9) Peningkatan produksi radikal bebas termasuk superoksida menyebabkan penurunan produksi NO dan berakhir dengan munculnya gejala preeklampsia. ${ }^{(10)}$ Terapi magnesium diharapkan dapat memperbaiki kondisi spasme vaskuler yang dijumpai pada kasus preeklampsia ${ }^{(11)}$, yang kemudian akan memperbaiki oksigenasi plasenta dan kondisi preeklampsia secara keseluruhan. 
Magnesium sulfat merupakan garam anorganik yang mengandung magnesium, sulfur dan oksigen. Kadar magnesium bebas dalam darah ibu dan janin pada kehamilan normal adalah $0.75 \mathrm{mmol} / \mathrm{L}$ dan $0.83 \mathrm{mmol} / \mathrm{L}$. Pada kondisi preeklampsia, angka ini ini berubah menjadi 0.66 mmol?1 pada serum ibu dan 1.01 pada serum janin. Walaupun belum ada penjelasan yang rinci mengenai potensi akumulasi $\mathrm{Mg}^{2+}$ dalam sirkulasi janin pada kasus preeklampsia, hal ini mungkin bisa menyebabkan gangguan pada metabolisme magnesium secara keseluruhan. Karena itu, mungkin menjadi penting untuk memepertahankan kadar $\mathrm{Mg}^{2+}$ plasma ibu yang lebih tinggi dari kadar fisiologisnya, untuk mengurangi efek buruk dari preeklampsia ${ }^{(12)}$. Di lain pihak, dosis magnesium yang berlebihan dapat menyebabkan intoksikasi yang berat, termasuk deperesi, bahkan sampai terhentinya pernafasan $^{(13)}$. Magnesium juga memiliki efek antihipertensi pada kasus preeklampsia berat. Sebuah penelitian di Jepang menunjukkan bahwa efek antihipertensi maksimum dicapai segera setelah pemberian dosis awal (loading dose) dan kemudian bertahan sampai persalinan ${ }^{(14)}$. Kadar terapeutik magnesium adalah $1.8-3.0 \mathrm{mmol} / \mathrm{L}^{(15)}$, atau sekitar 2-3.5 mmol/ $\mathrm{L}^{(16)}$, setara dengan 4.8 $8.4 \mathrm{mg} / \mathrm{dL}^{(13)}$ atau $4-7 \mathrm{mEq} / \mathrm{L}$.

Magnesium sulfat telah digunakan sebagai obat terpilih untuk mencegah terjadinya kejang, tetapi walaupun regimen yang sama telah dibuktikan efektif dan aman, tetap perlu untuk dijelaskan secara lebih rinci ${ }^{(17)}$. Cara pemberiannya adalah dengan bolus intravena untuk dosis awal dengan tujuan mencapai efek lebih cepat. Dosis pemeliharaan selanjutnya dapat diberikan secara infus intravena, dikenal sebagai protokol Zuspan, atau sebagai suntukan intramuskular berkala (protokol Pritchard). (15,18-20) Pada protokol Zuspan diikuti dengan cara memberikan 4-6 gram dosis awal magnesium sulfat $\left(\mathrm{MgSO}_{4}\right)$ yang dilarutkan dalam $100 \mathrm{~mL}$ cairan dan diberikan secara intravena perlahan, dalam waktu 15-20 menit. Berikutnya diberikan infus dengan dosis 2 gram/jam untuk pemeliharaan (sebagian pakar merekomendasikan $1 \mathrm{gram} / \mathrm{jam}$ ). Kemungkinan intoksikasi magnesium dipantau dengan cara memeriksa tendon secara berkala. Selain itu dapat dilakukan dengan mengukur kadar magnesium serum pada jam 4-6 untuk selanjutnya menyesuiakan dosis infus untuk mempertahankan kadar megnesium antara 4-7 mEq/L (atau 4.8-8.4 $\mathrm{mg} / \mathrm{dL}$ ). Pengukuran kadar magnesium serum dilakukan juga jika didapatkan kadar kreatinin serum $1.0 \mathrm{mg} / \mathrm{dL}$. Terapi magnesum sulfat dihentikan 24 jam setelah persalinan.

Sedangkan pada protokol Pritchard, pemberian 4 gram larutan $\left(\mathrm{MgSO}_{4}\right)$ 20\% secara bolus intravena dengan kecepatan kurang dari 1 gram/menit. Segera lanjutkan dengan pemberian 10 gram larutan $\mathrm{MgSO}_{4} 50 \%$ secara intramuskular pada otot gluteus, terbagi dua kiri dan kanan. Bila perlu bisa ditambahkan $1 \mathrm{~mL}$ lidocaine $2 \%$ untuk mengurangi nyeri saat penyuntikan. Jika kejang masih ada setelah 15 menit, berikan lagi 2 gram larutan 20\% secara intravena dengan kecepatan kurang dari 1 gram/menit. Jika pasien gemuk, dosis bisa dinaikkan sampai 4 gram secara perlahan-lahan. Untuk dosis pemeliharaan berikan injeksi 5 gram $\mathrm{MgSO}_{4} 50 \%$ secara berkala setiap 4 jam pada otot gluteus. Sebelum penyuntikan, pastikan bahwa; (a) refleks patella (+); (b) tidak ada deperesi pernafasan; (c) produksi urine dalam 4 jam sebelumnya lebih dari $100 \mathrm{~mL}$.Terapi magnesum sulfat dihentikan 24 jam setelah persalinan.

Melihat perbedaan jumlah dosis yang diberikan pada kedua protokol, kita perlu mengetahui apakah dosis yang diberikan pada keduanya tidak melebihi kadar terapeutik serum sehingga intoksikasi magnesium dapat kita hindari. Penelitian ini dilakukan untuk mengukur kadar magnesium serum pada perempuan dengan preeklampsia yang mendapat terapi $\mathrm{MgSO}_{4}$ dengan rute pemberian yang berbeda. Berbeda dengan penelitian-penelitian sebelumnya, penelitian ini dilakukan pada perempua Indonesia, dengan mengambil contoh serum dari 9 titik waktu selama terapi magnesium berjalan.

\section{METODE}

Penelitian ini merupakan penelitian uji klinik secara acak yang dilakukan pada Juni 2013Mei 2014 dengan lokasi di RSUD Subang, Jawa Barat. Subjek penelitian yaitu semua perempuan dengan preeklampsia. Dengan kriteria inklusi, semua perempuan dengan preeklampsia dari semua golongan usia dan paritas dengan kehamilan janin tunggal dan hidup, serta bersedia mengikuti penelitian. Kriteria eksklusi penelitian adalah 
jika didapatkan komplikasi kehamilan berupa perdarahan antepartum atau penyakit kronis lain seperti DM dan gangguan fungsi ginjal, serta mereka yang memiliki kontraindikasi untuk terapi magnesium.

Pengukuran jumlah sampel menggunakan rumus:

$$
\mathrm{N}_{1}=\mathrm{N}_{2}=2\left[\frac{\left[\mathrm{Z}_{\alpha}+\mathrm{Z}_{\beta}\right] \mathrm{S}}{\mathrm{X}_{1}-\mathrm{X}_{2}}\right]^{2}=\begin{aligned}
& 34.477052 \\
& \text { dibulatkan menjadi } 35
\end{aligned}
$$

Dengan :

$\alpha$ sebesar 5\% sehingga $Z \alpha=1.645$

$\beta$ sebesar $20 \%$ sehingga $Z \beta=0.842$

$\mathrm{S}^{(21)}=5.00836$

$\mathrm{X} 1-\mathrm{X} 2=3$ (rerata perbedaan kadar magnesium serum)

Tujuh puluh subjek penelitian diambil secara konsekutif (consecutive sampling), selanjutnya secara acak dibagi menjadi 2 kelompok. Kelompok pertama adalah kelompok dengan rute magnesium intravena dan kelompok kedua dengan suntikan intramuskuler secara berkala. Dosis yang digunakan pada kelompok intravena yaitu dosis awal dengan 4 gram larutan $\mathrm{MgSO}_{4} 20 \%$ diberikan secara bolus intravena perlahan selama 10-15 menit. Lalu pada dosis pemeliharaan berikan 1 gram/jam larutan $\mathrm{MgSO}_{4}$ $20 \%$ dilarutkan dalam larutan dan diberikan per infus.
Sedangkan pada kelompok intramuskuler dosis awal dengan 4 gram larutan $\mathrm{MgSO}_{4} 20 \%$ diberikan sebagai bolus intravena dalam 10-15 menit, langsung diikuti dengan pemberian 10 gram larutan $\mathrm{MgSO}_{4} 40 \%$ secara intramuskuler pada otot gluteus terbagi kiri dan kanan. Pada dosis pemeliharaan berikan 5 gram larutan $\mathrm{MgSO}_{4}$ $40 \%$ secara intramuskuler setiap 4 jam pada otot gluteus bergantian kiri dan kanan.

Setelah ditentukan subjek yang memenuhi kriteria penelitian, selanjutnya dilakukan pencatatan data berisi umur ibu, usia kehamilan, tekanan darah sistolik dan distolik serta pemeriksaan laboratorium darah awal meliputi pemeriksaan kadar hemoglobin, hematokrit, jumlah trombosit, kadar magnesium awal, kadar urea $\mathrm{N}$, kreatinin, serum glutamat oksaloasetat transaminase (SGOT) dan serum glutamat piruvat transaminase (SGPT). Data ini akan menjadi data demografik dan laboratorik awal dan akan dibandingkan antar kedua kelompok. Jika tidak didapatkan perbedaan yang bermakna antar kelompok, maka kadar magnesium serum selama terapi magnesium pada kedua kelompok layak untuk dibandingkan.

Pada analisis laboratorium kadar magnesium serum selanjutnya diperiksa dari sampel darah yang diambil pada menit ke 10, jam ke 1, 2, 4, 24, 26, 28 dan 30. Analisis statistik menggunakan uji independent sample t test untuk analisis data dengan tingkat kemaknaan $\mathrm{p}<0.05$.

Tabel 1. Karakteristik demografik dan laboratorik kelompok intra vena (IV) dan intra muskuler (IM)

\begin{tabular}{|c|c|c|c|}
\hline Variabel & $\begin{array}{c}\text { IV } \\
{[\mathbf{n}=35]} \\
{[\text { rerata } \pm \text { SD] }}\end{array}$ & $\begin{array}{c}\text { IM } \\
{[\mathbf{n}=\mathbf{3 5 ]}} \\
{[\text { rerata } \pm \text { SD] }}\end{array}$ & $\mathbf{p}$ \\
\hline Usia (tahun) & $30.2 \pm 7.7$ & $28.7 \pm 7.9$ & 0.572 \\
\hline Usia kehamilan (minggu) & $35.0 \pm 4.5$ & $36.1 \pm 3.9$ & 0.577 \\
\hline TD sistolik (mmHg) & $178.0 \pm 26.2$ & $175.7 \pm 28.9$ & 0.534 \\
\hline TD diastolik (mmHg) & $112.0 \pm 15.7$ & $109.7 \pm 15.6$ & 0.372 \\
\hline $\mathrm{MAP}[\mathrm{mmHg}]$ & $134.2 \pm 17.8$ & $129.3 \pm 16.1$ & 0.183 \\
\hline $\begin{array}{l}\text { Hasil pemeriksaan laboratoriu } \\
\text { Hemoglobin }[\mathrm{gr} / \mathrm{dL}] \\
\text { Hematokrit }[\%] \\
\text { Trombosit }\left[10^{3} / \mathrm{mm}^{3}\right] \\
\text { Kadar } \mathrm{Mg}[\mathrm{mg} / \mathrm{dL}] \\
\text { Urea }[\mathrm{mg} / \mathrm{dL}] \\
\text { Kreatinin }[\mathrm{mg} / \mathrm{dL}] \\
\text { SGOT }[\mathrm{U} / \mathrm{L}] \\
\text { SGPT }[\mathrm{U} / \mathrm{L}]\end{array}$ & $\begin{array}{c}11.05 \pm 1.44 \\
36.3 \pm 3.8 \\
249.97 \pm 68.85 \\
2.11 \pm 0.32 \\
23.34 \pm 8.52 \\
0.76 \pm 0.25 \\
28.43 \pm 21.77 \\
32.31 \pm 53.84\end{array}$ & $\begin{array}{c}10.34 \pm 1.45 \\
34.4 \pm 4.6 \\
267.03 \pm 88.33 \\
2.23 \pm 0.47 \\
21.31 \pm 7.96 \\
0.91 \pm 0.31 \\
22.80 \pm 12.48 \\
25.03 \pm 112.95\end{array}$ & $\begin{array}{l}0.505 \\
0.053 \\
0.116 \\
0.197 \\
0.432 \\
0.111 \\
0.129 \\
0.114\end{array}$ \\
\hline
\end{tabular}

Keterangan: $\mathrm{n}=$ jumlah sample, $\mathrm{SD}=$ standar deviasi, $\mathrm{TD}=$ tekanan darah, $\mathrm{mmHg}=$ milimeter hydrargirum, $\mathrm{gr} /$ $\mathrm{dL}=$ gram per desiliter, $\%=$ persen, $\mathrm{mm}^{3}=$ milimeter $\mathrm{kubik}, \mathrm{mg} / \mathrm{dL}=$ miligram per desiliter, $\mathrm{U} /$ $\mathrm{L}=$ unit per liter, $\mathrm{MAP}=$ mean arterial pressure (tekanan darah arterial rata-rata), $\mathrm{p}=$ tingkat kemaknaan. 
Tabel 2. Perbandingan kadar rerata magnesium serum pada kelompok intravena (IV) dan intramuskuler (IM)

\begin{tabular}{ccccc}
\hline \multirow{2}{*}{$\begin{array}{c}\text { kadar Mg serum } \\
\text { waktu pengambilan } \\
\text { contoh darah (jam) }\end{array}$} & IV & IM & \multicolumn{1}{c}{$\begin{array}{c}\text { Perbedaan } \\
\text { rerata }\end{array}$} & p \\
\cline { 3 - 5 } & Rerata \pm SD & Rerata \pm SD & & \\
\hline 0 & $2.11 \pm 0.32$ & $2.23 \pm 0.47$ & -0.12 & 0.197 \\
0.1667 & $4.67 \pm 1.23$ & $5.30 \pm 1.93$ & -0.64 & $0.005^{*}$ \\
1 & $3.83 \pm 1.03$ & $4.76 \pm 1.24$ & -0.92 & 0.196 \\
2 & $3.74 \pm 1.13$ & $4.85 \pm 1.15$ & -1.11 & 0.930 \\
4 & $3.52 \pm 0.87$ & $4.26 \pm 0.98$ & -0.74 & 0.547 \\
24 & $3.51 \pm 0.91$ & $4.15 \pm 1.26$ & -0.64 & 0.087 \\
26 & $3.11 \pm 2.03$ & $4.63 \pm 1.28$ & -1.52 & 0.138 \\
28 & $3.15 \pm 1.13$ & $4.30 \pm 1.33$ & -1.15 & 0.612 \\
30 & $2.94 \pm 1.08$ & $3.95 \pm 0.97$ & -1.01 & 0.862 \\
\hline
\end{tabular}

Keterangan: $\mathrm{mg} / \mathrm{dL}=$ miligram per desiliter, $\mathrm{SD}=$ standar deviasi, $\mathrm{p}=$ tingkat kemaknaan

Penelitian ini sudah mendapat persetujuan dari Komisi Etik untuk Penelitian Kedokteran dan Kesehatan Fakultas Kedokteran Universitas Gadjah Mada dengan nomor KE/FK/556/EC pada tanggal 23 Juli 2012.

\section{HASIL}

Berdasarkan data demografi (usia, usia kehamilan, tekanan darah sistolik/diastolik dan tekanan arterial rata-rata) serta data laboratorik (kadar hemoglobin, hematokrit, jumlah trombosit, kadar magnesium serum, urea $\mathrm{N}$, kreatinin, SGOT dan SGPT) tidak didapatkan perbedaan yang bermakna ( $p>0.05$ ) sehingga kedua kelompok layak untuk dibandingkan (Tabel 1).

Sampel darah vena selanjutnya diambil dari subjek penelitian pada waktu yang sudah ditentukan di atas (total 9 titik waktu) dan dilakukan pemeriksaan kadar magnesium serum. Hasil menunjukkan bahwa semua kadar magnesium serum pada kelompok intramuskuler lebih tinggi daripada kelompok intravena pada waktu yang sama, tetapi perbedaan yang bermakna hanya dijumpai pada sampel menit ke $10 \quad(\mathrm{p}=0.005)$ (Tabel 2). Pada titik waktu lainnya, perbedaan kadar magnesium serum pada kedua kelompok tidak bermakna $(p>0.05)$. Data menunjukkan bahwa kadar magnesium serum pada kedua kelompok masih berada dalam rentang kadar terapeutik (Gambar 1).

\section{PEMBAHASAN}

Hasil menunjukkan bahwa perbedaan bermakna dari kadar magnesium serum hanya ditemukan pada sampel darah menit ke 10 (segera setelah pemberian dosis awal). Perbedaan yang bermakna ini mungkin disebabkan karena adanya perbedaan dosis awal (loading dose) yang diberikan, dimana untuk kelompok intramuskuler ada tambahan dosis 10 gram $\mathrm{MgSO}_{4} 40 \%$ yang diberikan intramuskuler.

Kondisi yang berpengaruh pada perubahan kadar magnesium serum adalah kondisi ginjal. Alasannya adalah karena magnesium tidak dimetabolisme, dan eliminasinya hanya denagn ekskresi melalui ginjal. Adaptasi maternal terhadap kehamilan melibatkan perubahan besar pada hemodinamik ginjal, termasuk 40$65 \%$ peningkatan laju filtrasi ginjal (glomerular filtration rate).(22) Perempuan preeklampsia seringkali memiliki gangguan fungsi ginjal yang mungkin dapat berdampak pada ekskresi magnesium melalui ginjal.

Data menunjukkan terdapat perbedaan kadar magnesium serum pada kedua rute pemberian. Walaupun begitu, jika dibandingkan dengan rentang kadar terapeutik magnesium ternyata sebagian besar kadarnya pada kelompok intravena masih berada di bawah rentang tersebut, sedangkan untuk kelompok intramuskuler seluruhnya terdapat dalam rentang terapeutik (Gambar 1). Hal ini menunjukkan bahwa dosis yang digunakan tidak melampaui batas keamanan terapi. Dari seluruh subjek yang ikut pada penelitian, tidak ada kasus yang menunjukkan gejala kejang. Hasil ini sesuai dengan hasil penelitian di Israel, yang menyimpulkan bahwa kebanyakan perempuan yang mendapat terapi magnesium dengan dosis pemeliharaan 1 gram/ jam, tidak mencapai kadar terapeutik magnesium serum. ${ }^{(16,23)}$ Dari hasil tersebut para peneliti menduga, kemungkinan kadar efektif magnesium 


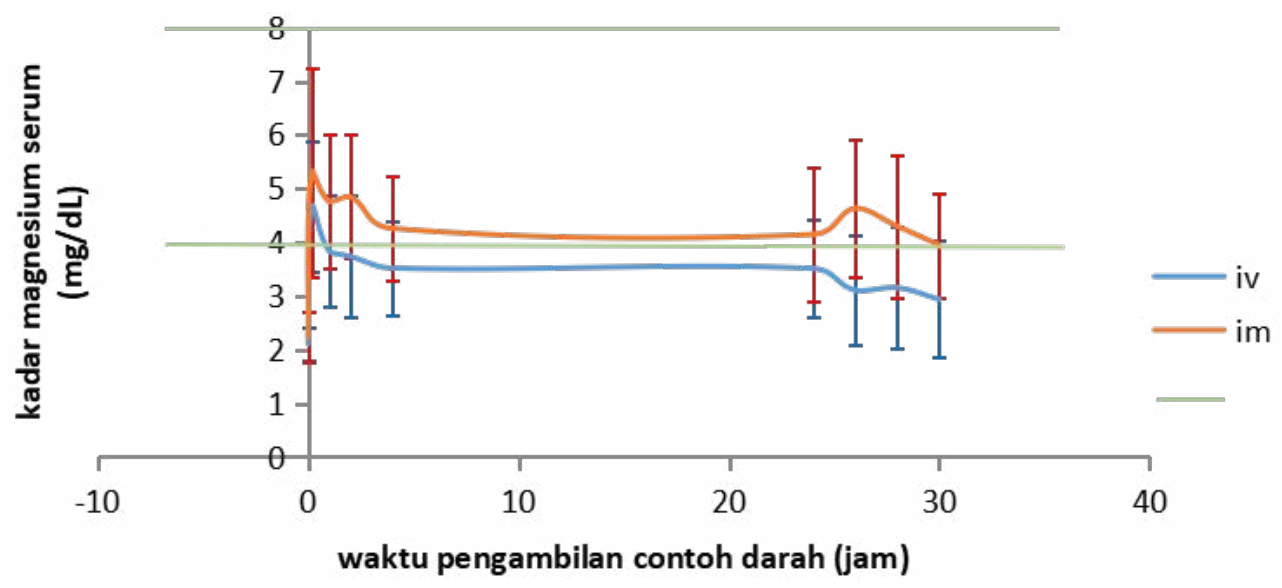

\section{Gambar 1. Kadar rerata magnesium serum selama terapi magnesium pada kelompok intravena (IV) dan intra muskuler (IM)}

serum minimal adalah lebih rendah dari yang sudah diketahui sebelumnya, dan dengan rentang yang mungkin lebih lebar. ${ }^{(16)}$

Penelitian lain di India membandingkan terapi magnesium protokol Zuspan dengan terapi magnesium dosis rendah (dikenal sebagai protokol Dhaka). Protokol Dhaka ini menggunakan dosis 4 gram larutan $\mathrm{MgSO}_{4} 20 \%$ yang diberikan dengan bolus intravena perlahan-lahan (dalam 10-15 menit), dan segera dilanjutkan dengan pemberian 6 gram larutan $\mathrm{MgSO}_{4} 50 \%$ intramuskuler terbagi dua yaitu pada otot gluteus kiri dan kanan sebagai dosis awal dan untuk dosis pemeliharaan diberikan 2.5 gram larutan $\mathrm{MgSO}_{4} 50 \%$ secara intramuskuler tiap 4 jam. Penelitian ini menemukan bahwa jumlah subjek yang mencapai kadar magnesium dalam rentang terapeutik pada protokol Dhaka adalah separuh dari jumlah subjek yang menerima protokol Zuspan. Selain itu juga ditemukan lebih banyak subjek dengan protokol Zuspan yang mengalami kehilangan refleks patella. ${ }^{(24)}$

Dalam pemberian pengobatan, efektivitas sama pentingnya dengan keamanan pengobatan. Karena itu, kita harus hati-hati dalam menentukan dosis yang tepat serta cara pemberian yang sesuai untuk semua penderita preeklampsia, dan menyesuaikannya dengan kondisi spesifik dan keadaan pasien. Rencana ke depan dibutuhkan penelitian selanjutnya dengan jumlah subjek yang lebih besar dan lebih bervariasi dalam hal kondisi dan komplikasi preeklampsia untuk mencari dosis optimum pada tiap kondisi sehingga keamanan terapi magnesium dapat ditingkatkan.

\section{KESIMPULAN}

Dosis magnesium yang lebih tinggi pada protokol Pritchard (IM) menyebabkan kadar dalam serum yang lebih tinggi dibanding kelompok IV, namun aman karena masih berada dalam kadar terapeutik.

\section{KONFLIK KEPENTINGAN}

Penulis menyatakan tidak ada konflik kepentingan dalam penelitian ini.

\section{REFERENSI}

1. The American College of Obstetricians and Gynecologists. Task Force on Hypertension in Pregnancy. Hypertension in pregnancy. Washington,DC; 2013.

2. Ngene NC, Moodley J. Role of angiogenic factors in the pathogenesis and management of preeclampsia. Int J Gynecol Obstet. 2018;141(1):513.

3. Myatt L, Roberts JM. Preeclampsia: syndrome or disease? Curr Hypertens Rep. 2015;17(11):83.

4. Bills V, Varet J, Millar A, Harper S, Soothill P, Bates D. Failure to up-regulate VEGF165b in maternal plasma is a first trimester predictive marker for pre-eclampsia. Clin Sci. 2009;116:265-72.

5. Triunfo S, Crovetto F, Crispi F, Rodriguez-Sureda $\mathrm{V}$, Dominguez C, Nadal A, et al. Association of first-trimester angiogenic factors with placental histological findings in late-onset preeclampsia. Placenta. 2016;42:44-50.

6. Cunningham FG, Leveno KJ, Bloom SL, Hauth JC, Rouse DJ, Spong CY. Williams obstetrics. 23rd ed. Twickler D, Wendel G, editors. New York: McGraw-Hill Education; 2010.

7. Hubel $\mathrm{C}$ a., Sipos PI, Crocker IP. Endothelial progenitor cells: Their potential role in pregnancy and preeclampsia. Vol. 1, Pregnancy Hypertension: An International Journal of Women's Cardiovascular Health. 2011. p. 48-58.

8. Ozkor MA, Murrow JR, Quyyumi AA. Endothelium: Dysfunction and Repair. In: 
Advances in Vascular Medicine. Springer; 2010. p. 187-210.

9. $\mathrm{Wu} \mathrm{F}$, Tian $\mathrm{F}$, Lin $\mathrm{Y}, \mathrm{Xu}$ W. Oxidative stress: placenta function and dysfunction. Am J Reprod Immunol. 2016;76(4):258-71.

10. Covarrubias AE, Lecarpentier E, Lo A, Salahuddin S, Gray KJ, Karumanchi SA, et al. Response and Oxidative Stress in Hypoxia-Exposed Trophoblasts: Relevance AP39, a Modulator of Mitochondrial Bioenergetics, Reduces Antiangiogenic Response and Oxidative Stress in Hypoxia-Exposed Trophoblasts Relevance for Preeclampsia Pathogenesis. Am J Pathol [Internet]. 2018;189(1):104-14. Available from: http://dx.doi.org/10.1016/j.ajpath.2018.09.007

11. Torshin IY, Gromova O. Magnesium and pyridoxine: fundamental studies and clinical practice. Nova Science Publishers; 2009.

12. Chiarello DI, Marín R, Proverbio F, Coronado $\mathrm{P}$, Toledo F, Salsoso R, et al. Mechanisms of the e ff ect of magnesium salts in preeclampsia. 2018;69(April):134-9.

13. Leetheeragul J, Boriboonhirunsarn D, Reesukumal K, Srisaimanee N, Horrasith S, Wataganara T. A retrospective review of on-admission factors on attainment of therapeutic serum concentrations of magnesium sulfate in women treated for a diagnosis of preeclampsia. J Matern Neonatal Med [Internet]. 2018;0(0):1-9. Available from: https:// doi.org/10.1080/14767058.2018.1489531

14. Takenaka S, Matsuoka R, Maruyama D. Magnesium sulfate has an antihypertensive effect on severe pregnancy induced hypertension. 2016;11-5.

15. Lu JF, Nightingale CH. Magnesium sulfate in eclampsia and pre-eclampsia. Clin Pharmacokinet. 2000;38(4):305-14.

16. Okusanya BO, Oladapo OT, Long Q, Lumbiganon P, Carroli G, Qureshi Z, et al. Clinical pharmacokinetic properties of magnesium sulphate in women with pre-eclampsia and eclampsia. Vol. 123, BJOG: An International Journal of Obstetrics and Gynaecology. 2016.

17. Cunningham FG, Nelson DB. Magnesium sulphate : too much of a good thing ? 2015;2015.

18. Cunningham FG, Leveno KJ, Bloom SL, Spong CY, Dashe J, Hoffman B, et al. Williams Obstetrics. 24th ed. Cunningham FG, Leveno KJ, Bloom SL, Spong CY, Dashe J, Hoffman B, et al., editors. New York: McGraw-Hill education; 2014.

19. Abad C, Vargas FR, Zoltan T, Proverbio T, Pinero $\mathrm{S}$, Proverbio F, et al. Magnesium sulfate affords protection against oxidative damage during severe preeclampsia. Placenta. 2015;36(2):179-85.

20. Pratt JJ, Niedle PS, Vogel JP, Oladapo OT, Bohren $\mathrm{M}$, Tuncalp $\mathrm{O}$, et al. Alternative regimens of magnesium sulfate for treatment of preeclampsia and eclampsia: A systematic review of nonrandomized studies. Vol. 95, Acta Obstetricia et Gynecologica Scandinavica. 2016.

21. Manorot $M$, Tongsong $T$, Khettglang $T$. A comparison of serum magnesium sulfate levels in pregnant women with severe preeclampsia between intravenous and intramuscular magnesium sulfate regimens: a randomized controlled trial. J Med Assoc Thai [Internet]. 1996 Feb [cited 2014 May 28];79(2):76-82. Available from: http://www.ncbi. nlm.nih.gov/pubmed/8868017

22. Brookfield KF, Su F, Elkomy $\mathrm{MH}$, Drover DR, Lyell DJ, Carvalho B. Pharmacokinetics and placental transfer of magnesium sulfate in pregnant women. Am J Obstet Gynecol [Internet]. 2016;214(6):737.e1-737.e9. Available from: http:// dx.doi.org/10.1016/j.ajog.2015.12.060

23. Yefet E, Braester Y, Suleiman A, Nachum Z. The effect of magnesium sulfate at 1 gram versus 2 grams maintenance doses on serum magnesium concentrations and adverse effects profile in women with severe pre-eclampsia. Am J Obstet Gynecol [Internet]. 2017;216(1):S504-5. Available from: http://dx.doi.org/10.1016/j.ajog.2016.11.793

24. Saha PK. Safety and ef fi cacy of low dose intramuscular magnesium sulphate ( $\mathrm{MgSO} 4$ ) compared to intravenous regimen for treatment of eclampsia. 2017;43(10):1543-9. 